\title{
The Formation and Evaluation of the Faulted Topography in the Burdur Basin, Lakes Region, SW Anatolia
}

\section{Göller Yöresi’ndeki Burdur Havzasında Faylı Yapının Oluşumu ve Evrimi}

\author{
İbrahim ATALAY ${ }^{1} \oplus$, Sevda ALTUNBAŞ ${ }^{\oplus}$, Muzaffer SILER ${ }^{3} \oplus$ \\ ${ }^{1}$ Karabük University, Department of Geography, Karabük, Turkey \\ ${ }^{2}$ Akdeniz University, Department of Soil Science and Plant Nutriment, Antalya, Turkey

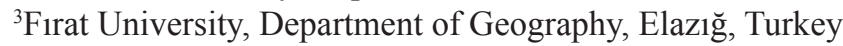

ORCID: İ.A. 0000-0002-0327-1485; S.A. 0000-0001-9779-9784; M.S. 0000-0001-5485-7008

\begin{abstract}
The Burdur Basin, which is located in the Lakes Region in SW Anatolia, was formed by vertical faulting movements. The erosion surfaces were developed on the marl deposit in accordance with the lowering of the base level in each faulting movement in the east of the Burdur Basin. These erosion surfaces are at an elevation of $980,995,1040,1115,1200,1300-1340$ m on the Neogene marl deposit and knickpoints along the valleys indicate six times depressed along the fault lines of the Burdur Basin. The fault scarp extending on the east of the Burdur Basin was dissected deeply as a triangular facet; the accumulation of materials that had been transported from the highlands led to the formation of dejection fans, cones and re-deposited marl deposit in the eastern part of the Lake Burdur Basin.

Earthquakes have occurred frequently since historical times and the subsidence that has taken place in the deeper part of Lake Burdur has attained a depth of more than $70 \mathrm{~m}$ in the southern part of the lake which may indicate continued tectonic activity. Lake Burdur, which is the remnant of Neogene Lake, containing some heavy minerals supports the life of only one species of fish and poor flora and fauna.
\end{abstract}

Keywords: Faulted structure, erosion surface, Burdur-Gölhisar Basin

\section{ÖZ}

Burdur Havzası, Üst Miyosen'den başlayarak Holosen başlarına kadar süren dikey faylanmalarla oluşmuş, fayların gençleşmesiyle alçalan taban seviyesine göre, özellikle Burdur havzasının doğusunda neojen marnları üzerinde 980, 995, 1040, 1115, 1200 ve 1300-1340 m yüksekliklerinde altı adet aşınım yüzeyi meydana gelmiştir. Tarım yapılan bu aşının basamakları ile akarsu vadileri boyunca tespit edilen eğim kırıklıkları, Burdur Havzası́nın altı kez çöktüğünü göstermektedir. Bu çökmeye bağlı olarak Burdur havzasının doğusundaki fay dikliği, geçici akarsu ve sellerle façetalar halinde derin olarak yarılmış; buradan taşınan malzemelerin birikmesiyle de Burdur Gölü doğrusunda uzanan birikinti koni ve yelpazeleri ile yeniden biriken marn depoları oluşmuştur. Toprak oluşumu için yeterli zamanın geçtiği 1100 m’nin üzerindeki aşınım yüzeylerindeki marnlar üzerinde oluşan rendzina topraklarına daha alt seviyelerdeki aşınım düzlüklerinde rastlanılmamaktadır. Fay dikliğini yaran akarsu vadilerinde eğimin çok fazla olması, bünyesine su alarak şişen marnların sürekli olarak yamaç akmaları haline taşınmasına yol açması, bitki örtüsünün gelmesini engellemektedir. Oyuntularla parçalanan eğimli sahalar, arazi degradasyonuna uğrayan hassas alanlardır.

Halen Burdur Havzası'nda tarihi dönemlerden beri sıkça oluşan depremler ve Burdur Gölü'nün güneyinde 70 m'yi aşan en derin yerde subsidansın sürmesi, tektonik hareketlerin devam ettiğini göstermektedir. Neojen gölünün bir bakiyesi olan Burdur Gölü, bazı ağır metaller içermesi nedeniyle bir balık türü dışında ve çok az sayıda floranın yaşadığı bir su ortamı özelliğindedir.

Anahtar kelimeler: Faylı yapı, aşınım yüzeyi, Burdur-Gölhisar havzası

Submitted/Başvuru: 03.04.2020 • Revision Requested/Revizyon Talebi: 05.05.2020 • Last Revision Received/Son Revizyon: 24.11 .2020 • Accepted/Kabul: 25.11.2020 • Published Online/Online Yayın: 25.12.2020

Corresponding author/Sorumlu yazar: Muzaffer SiLER / msiler@firat.edu.tr

Citation/Atıf: Atalay, I., Altunbas, S., \& Siler, M. (2020). The formation and evaluation of the faulted topography in the Burdur basin, lakes region, SW Anatolia. Cografya Dergisi, 41, 179-192. https://doi.org/10.26650/JGEOG2020-0016 


\section{INTRODUCTION}

Faulted topography presents many interesting topographic features depending on faulting movements. Topography associated with high-angle normal faults has been more frequently described than any other type because of the blocks of the earth's crust relatively raised as horst and lowered as graben between more or less parallel faults. The grabens are seen in Jordan-Dead Sea Depression, Death Valley, the Rhine Graben, and the Rift valley of Eastern Africa. Examples of horsts throughout the world are the Vosges Mountains to the west of the Rhine Graben, the Schwarzwald or Black Forest Plateau to the east of it, the Palestine Plateau to the west of the Dead Sea and the plateau of TransJordanian to the east of it (Strahler et al., 1983; Thornbury 2004). The horst graben system presents special topographic features in terms of erosion and sedimentation processes.

Field studies relating to geologic, geomorphologic properties and its evaluation of the study area were started in the 1860's with the studies of P. de Tchihatcheff (1867), and continued in the research of H. Louis (1938), İlhan (Lahn) (1948), Ardel (1952), and the changing of lake level was firstly introduced by Cohen and Erol (1969), Erol (1972), Sungur (1974), Atalay (1977), Atalay et al., (2019a). The first time the faulted topography and its properties were studied was by Atalay (1977) and Atalay et al., $(2017 \mathrm{~b}, \mathrm{c})$; pedogeomorphologic properties of the Burdur basin were introduced by Altunbaş (2018). Detailed field studies were carried out between 2017 and 2019.

The shaping of the present-day topography of Turkey, especially in the Anatolian Peninsula, mainly depends on the vertical tectonic movements, called the neotectonic period, which roughly occurred between Middle-Miocene and Upper Holocene (Erol, 1981; 1984; Atalay, 2017). In Anatolia, the compressional and extensional movements have led to the formation of horst-graben systems along the strike-slip and high-angle fault lines. During the Middle Miocene the eastern part of Anatolia was subjected to compression due to the north forward direction of the rigid Arabian Platform. The compression tectonic regime in East Anatolia is the main factor responsible for the formation of pull-apart basins along the Eastern and Northern Anatolian strike-slip fault line zones. At the same time, high-angle normal faults in the zones of the Eastern Anatolian Fault and North Anatolian Fault also caused the formation of the tectonic basin (Şengör, 1980; Şengör et al., 1983; Şaroğlu et al., 1987; Atalay 2017). In the Eastern Anatolian Fault Zone, many grabens extending in the direction of SE to NW are found: AntakyaMaraş, Pazarcık, Gölbaşı, Lake Hazar, Bingöl Basin and Karlıva. The main grabens in the North Anatolian Fault Zone are found on the tectonic corridor of Karlıova, Erzincan, Kelkit, Merzifon, Tosya-Ilgaz Bolu, Adapazarı and İzmit. In the western part of Anatolia, extensional tectonic regime has led to the formation of horst-graben topography. The grabens extending in direction of E-W from north to south in the western part of Anatolia are Edremit, Bakırçay, Gediz, Küçük (Small) Menderes and Büyük (Big) Menderes (Meander). The rivers flowing into Aegean Sea were established on the grabens; the mountains fit the horsts in the western part of Anatolia. The faulting movements have played an important role in the shaping of the present-day topography of Turkey (Atalay, 2007; 2013; 2017). These fault zones correspond to the main earthquake zones of Turkey. The last earthquake occurred in May 1971 in the Burdur depression (Erinç et al., 1971).

The Lakes Region, which is located between the western continuation of Taurus Mountains and the Menderes Palaeozoic metamorphic masse, contains many tectonic grabens some of which were occupied by lakes. These grabens or depressions occupied by the lakes are Lake Acı, Lake Burdur, Lake Eğirdir and Lake Beyşehir and the plains encircling the lakes correspond to the chief settlement areas and agricultural fields of Turkey. In this study, the formation of faulted topography and evaluation of the Burdur Lake basin, which is located in the Burdur-Gölhisar Basin, is examined.

\section{MATERIALS AND METHODS}

Detailed field studies were carried out between 2017 and 2019. In the field studies, a topographic map in the scale of $1 / 25,000$ was used and a geologic map prepared by the Mineral Research and Exploration Institute (MTA) in the scale of $1 / 100,000$ was modified. In order to illuminate the geomorphic evolution, especially the interrelationship between faulting movement and fluvial erosion, the profiles showing erosion surfaces, faulting movements and the knickpoint of the talveg profile were drawn. Some photos were added to show topographic-geomorphic and geologic properties of the study area. The main aim of this study is to elucidate the formation of faulting movements and its effects on the rejuvenation of fluvial erosion and deposition.

\section{FINDINGS}

\subsection{Topographic properties}

The Burdur-Gölhisar Basin, which is located in the western part of the Lakes Region in SW Anatolia, is one of the intermontane basins lying between the western part of the Taurus Mountain Range in the east and the Sögüt Mountains in the west. 
Geomorphologically, the Burdur Basin, at the same time, is found between the Menderes Palaeozoic metamorphic and the Taurus Mountain orogenic belt (Atalay et al., 2017a). The Burdur Lake Basin contains two small plains in the northern and southern parts of Lake Burdur (Figure 1). A small shallow lake named Yarışlı Lake is found in the southern end of the Lake Burdur Plain and its shallow ground water flows into Lake Burdur. The lower part of the Burdur depression is occupied by the closed Burdur Lake. For this reason, the water of the lake is salty and brackish. Its water level has been changed in response to climatic changes, which occurred in Upper Pleistocene and Early Holocene. But recently, the Burdur lake level has decreased due to the dams that have been constructed on the streams feeding the lake in order to obtain irrigation and domestic water. The increased salty ground water due to the lowering of the lake level, rising with capillarity, causes the salinization process on the presently regressed lake area.

The altitude, which is at an elevation of $850 \mathrm{~m}$ in Lake Burdur, rises up to 2,500 $\mathrm{m}$ in Katrancik Hill in the east and 2000 $m$ of elevation in the Söğüt Mountains in the west. The inclination of fault scarps in the eastern and western part of Lake Burdur is more than $100 \%$. Marl deposit has been deeply dissected as deep gullies by the streams flowing into Lake Burdur in the eastern part of the Burdur Basin, but this topographic form is not seen in the western part of the Burdur Basin due to the existence of limestone and the conglomerate which are resistant against fluvial erosion. Thus, this different type of topographic form in the study area is mainly related to faulting movement and the erodibility properties of the geologic parent materials.

\subsection{Geologic setting}

The basement of the study area occurring in the Tethys Sea basin is mostly composed of peridotite that mostly erupted and spread from the mid-oceanic ridge on the floor of the Tethys geosyncline bottom and serpentine formed the result of hydration of peridotite in the Mesozoic era. The mud-rich calcareous and clayey materials accumulated on the peridotite and serpentine basement of the geosyncline. Thus, the thick limestone mass attaining more than $500 \mathrm{~m}$ was formed and emerged with the uplifting and folding of the mud-rich calcareous and clayey materials in the Upper Mesozoic period. Tertiary conglomeratesandstone formation was formed with the accumulation of transported materials such as sands and gravels originating from Mesozoic limestone and partly peridotite-serpentine terrains in the north-western part of the Sögüt Mountains. Melange, composed of peridotite-serpentine and limestone, was formed during the Alpine orogenic movements, which occurred at the end of Oligocene (Ketin 1983, Atalay 2017).

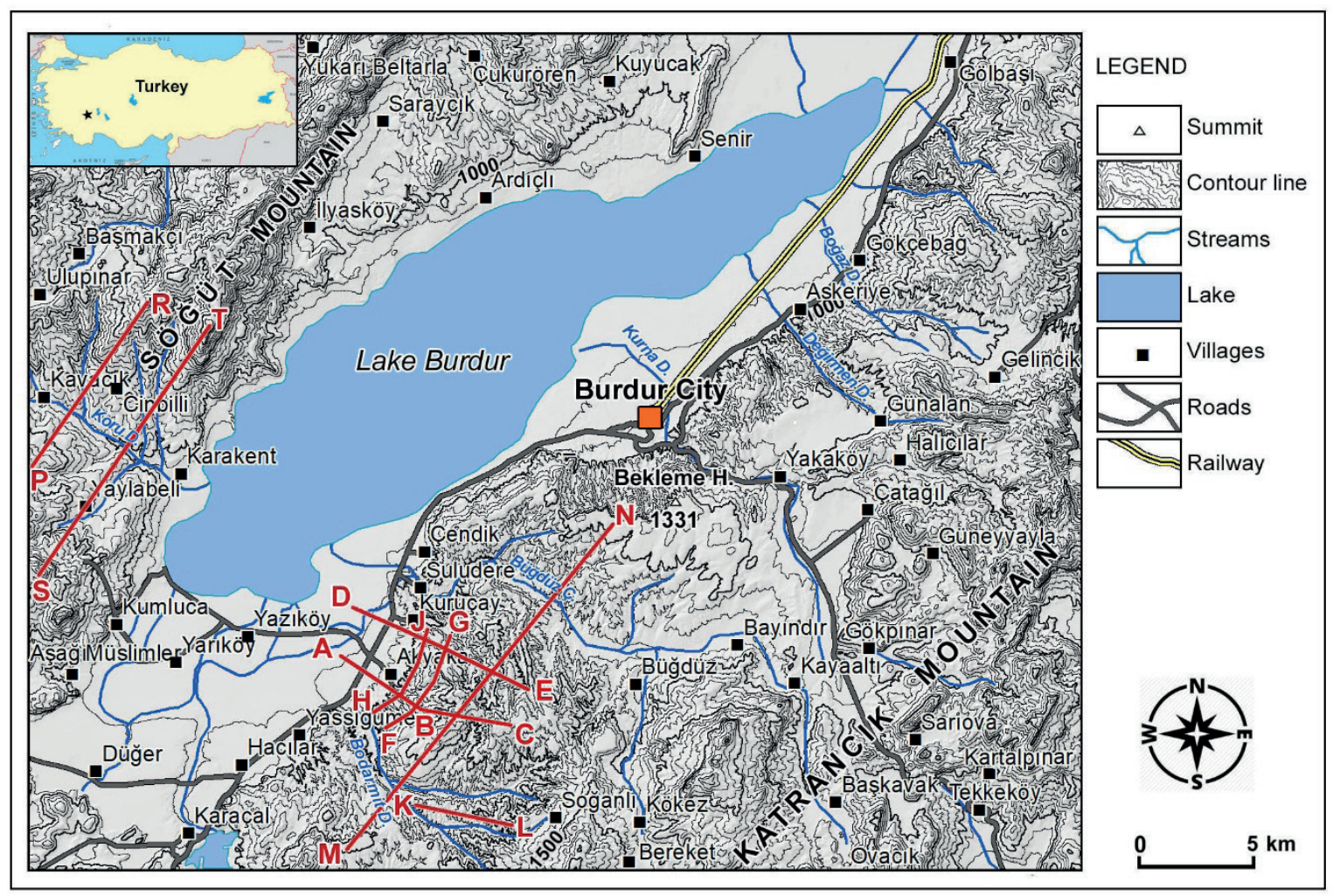

Figure 1: Location, topographic and profile lines of the Burdur Basin. 


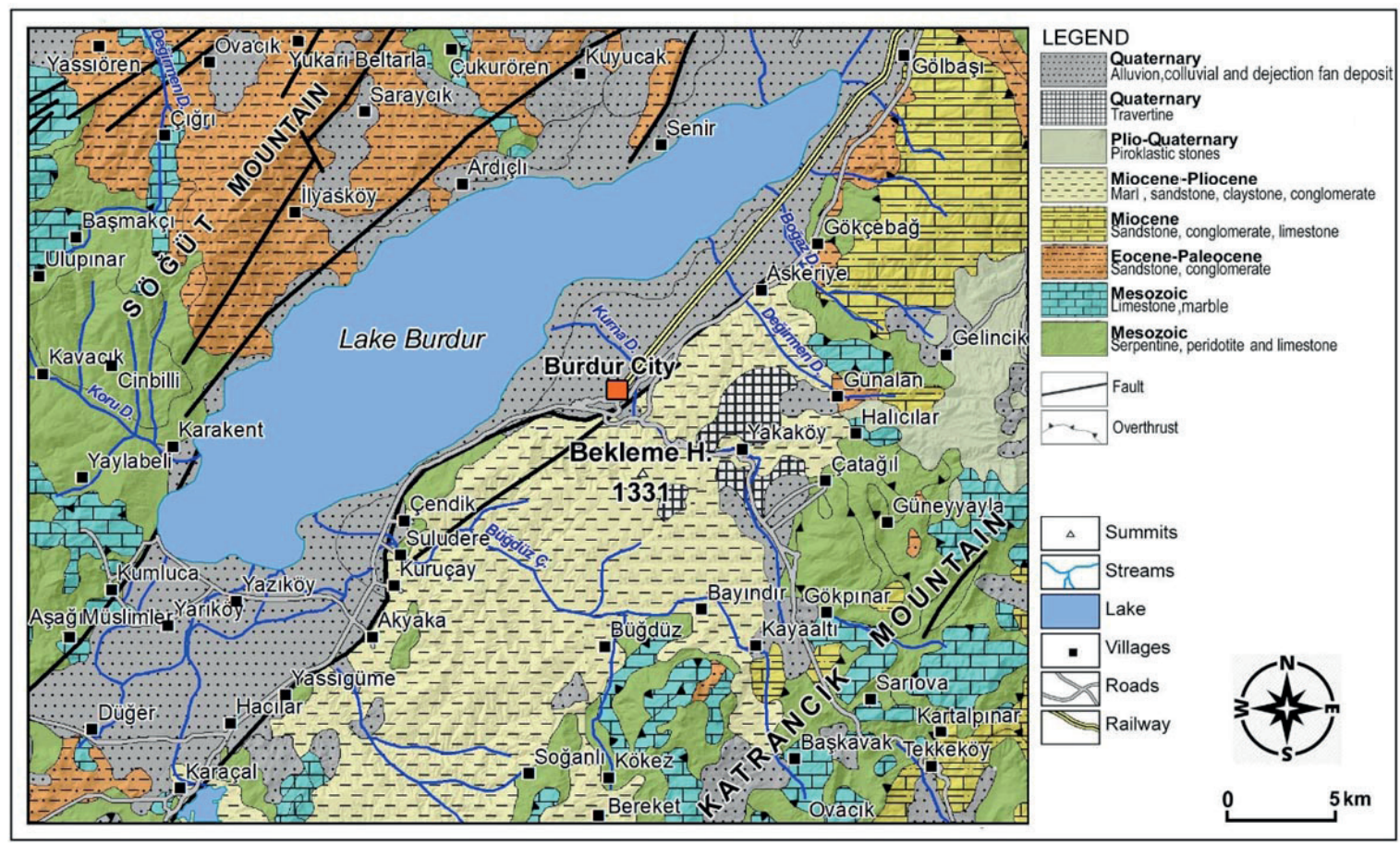

Figure 2: Geologic map of the Burdur Basin.

After the Alpine orogeny, vertical tectonic movements leading to faulting started in the middle Miocene and continued into the late Quaternary. The present-day Burdur basin probably first collapsed in the Middle Miocene and the collapsed area was occupied by the lake in which mostly marl material was deposited (Atalay, 1977; Atalay et al., 2019a) (Figure 2, 3). The fluvial gravelly deposit in the marl deposit indicates the regression in the lake facies and the inclination of the marl layer shows the existence of epeirogenetic movement (Photo 1, 2).
3.3. Main topographic-geomorphic features of the faulted topography

Faulted topography in the eastern part of the Burdur Basin is a good example of the faulted topography not only for the Lakes Region but also other parts of Turkey. Erosion surfaces on the marl deposit, terraces and knickpoints along the valley profiles clearly reflect the faulting movements controlled by the shape of the faulted topography.

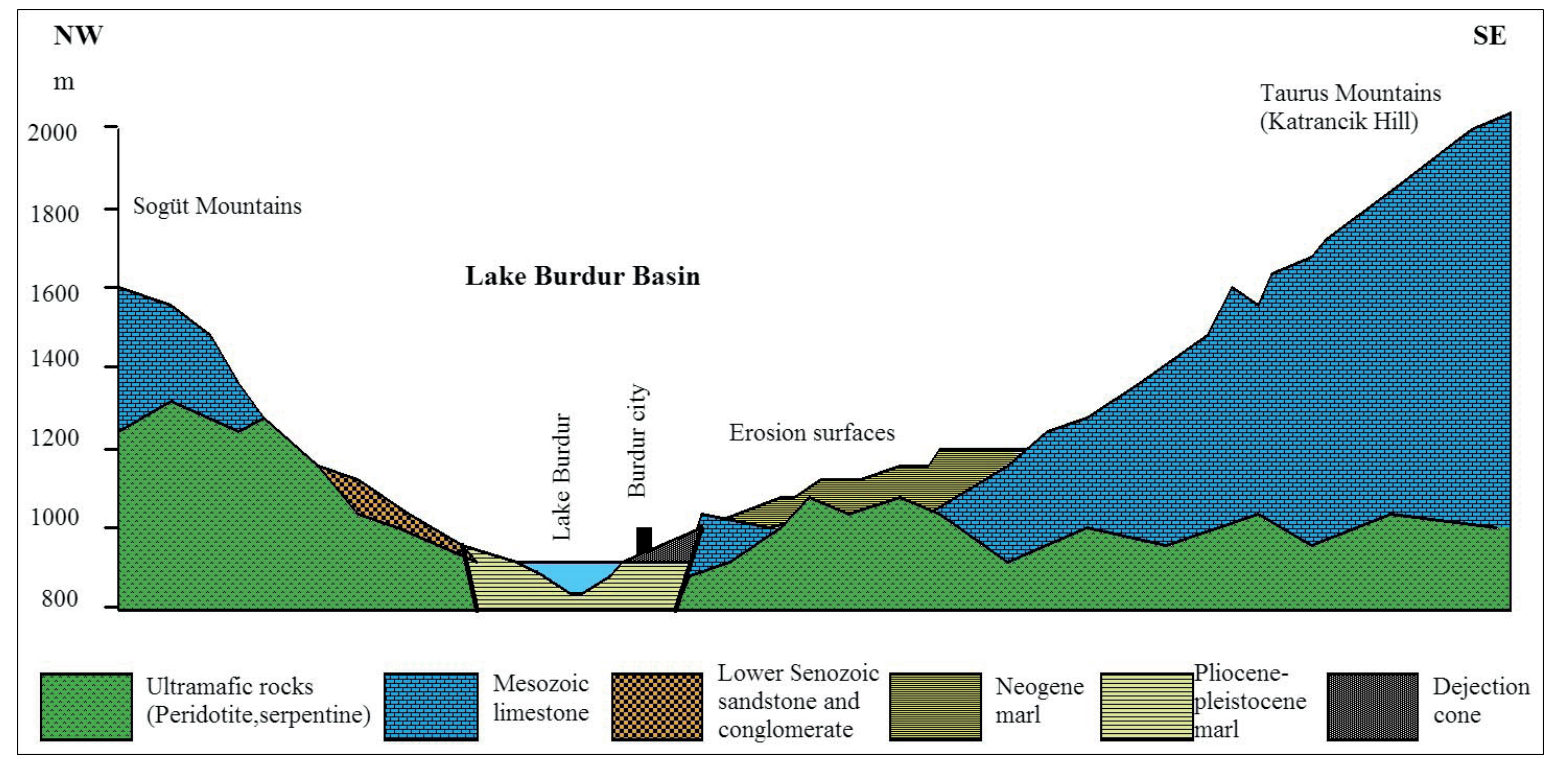

Figure 3: General topographic profile and geologic cross-section of the Burdur Basin. 


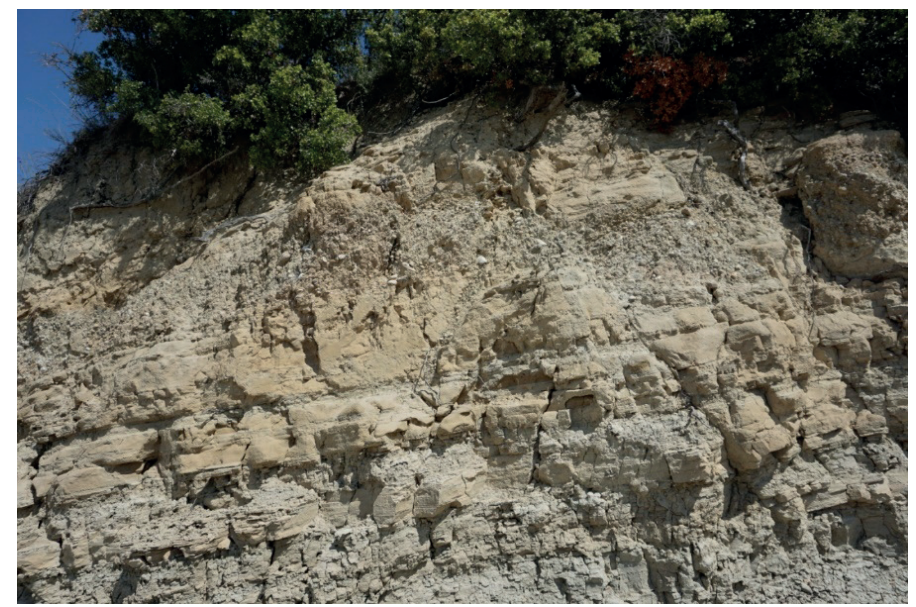

Photo 1: Marl deposit and fluvial gravels indicating regression phases in the lake facies in the Burdur Basin.

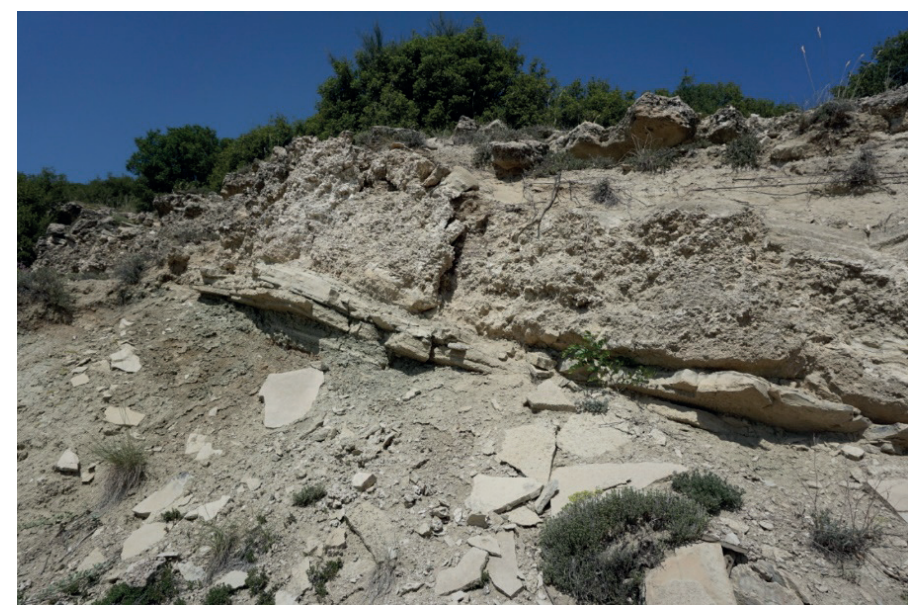

Photo 2: Inclined marl layer and rounded fluvial gravel layer also showing the epirogenesis movement in the Burdur Basin.

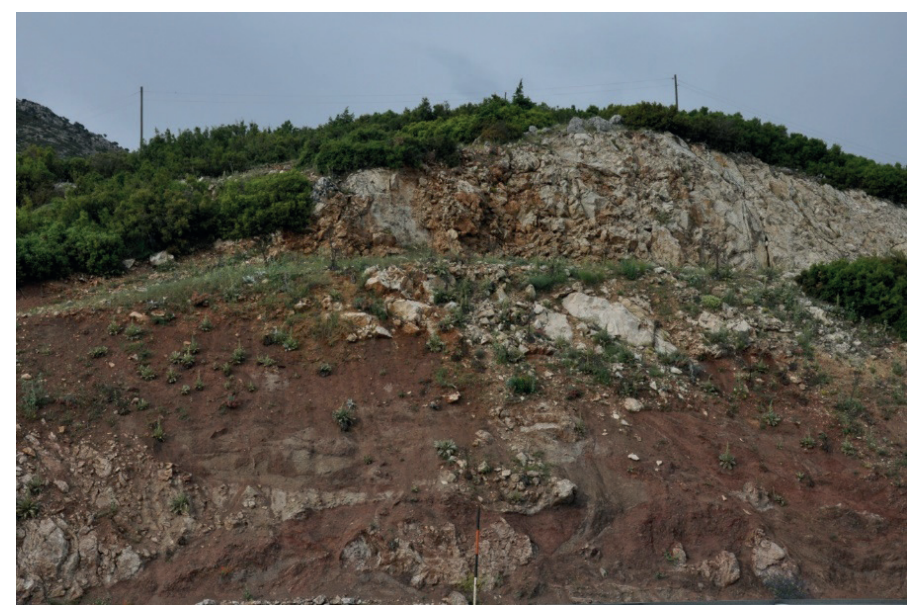

Photo 3: A melange composed of Mesozoic limestone and weathered peridotite-serpentine outcropped with the exhumation of marl deposit along the main fault line extending in the east of the Burdur Basin.

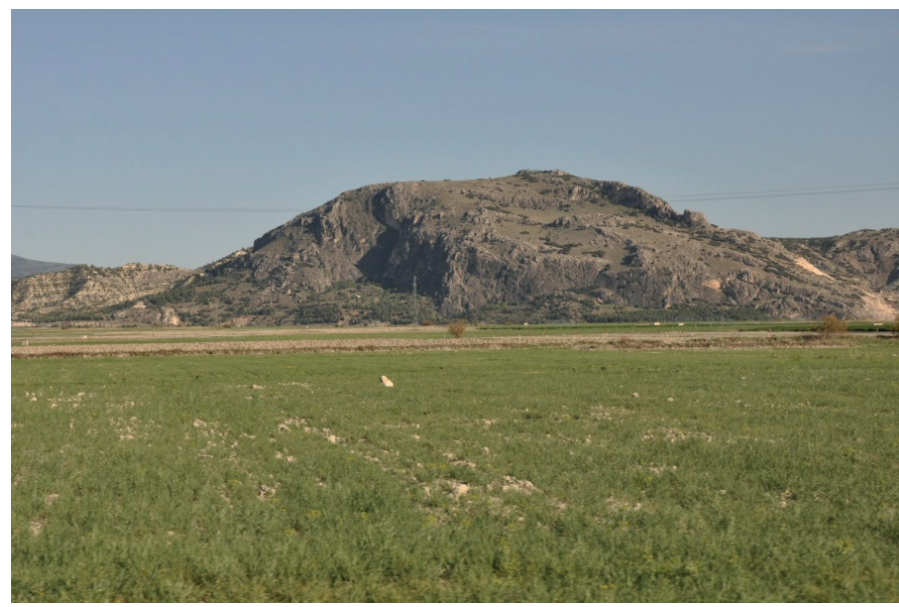

Photo 4: The Fault scarp and overlying Neogene marl deposits occurring on two sides of the fault scarp and the alluvial plain of the Burdur Basin.

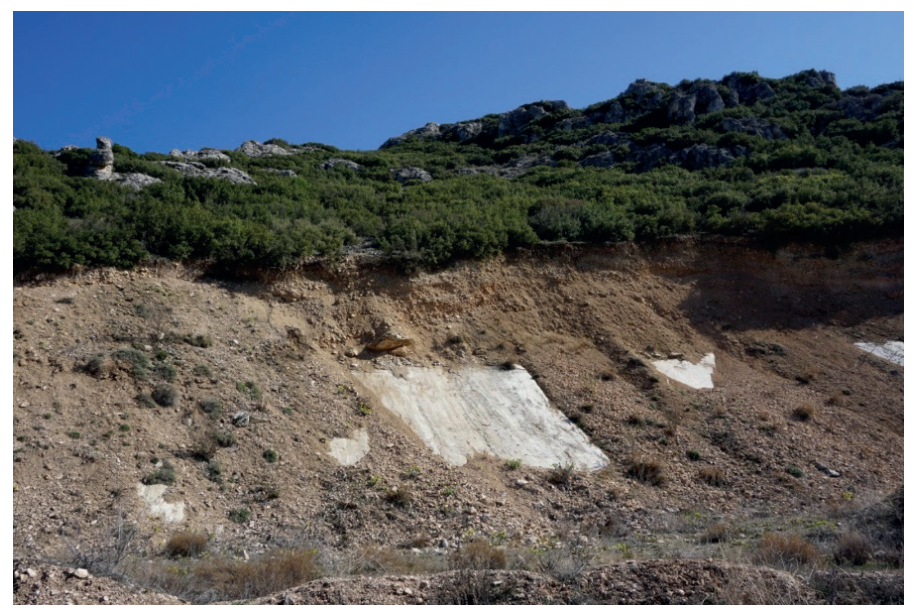

Photo 5: Fault mirror exposed with the exhumation of colluvial deposit crossing the Burdur main fault line at Yassıgüme.

The main topographic-geomorphic and topographic forms are mentioned below.

\section{Erosion surfaces}

Erosion surfaces, which are found at an elevation of 1,3001,350, 1,200, 1,115, 1,040, 995 and $980 \mathrm{~m}$, were developed on Neogene marl deposit in accordance with the base levels of the Burdur Basin. In other words, each erosion surface clearly shows the collapse periods of the Burdur Basin and levelling of the upland area as flat land with fluvial agents according to base level of the Burdur Basin (Figure 4, 5).

Upper erosion surfaces extending at an elevation of 1,300$1,350,1,200$, and 1,115 $\mathrm{m}$ are chiefly agricultural fields on which mostly cereals are harvested by peasants to obtain domestic 


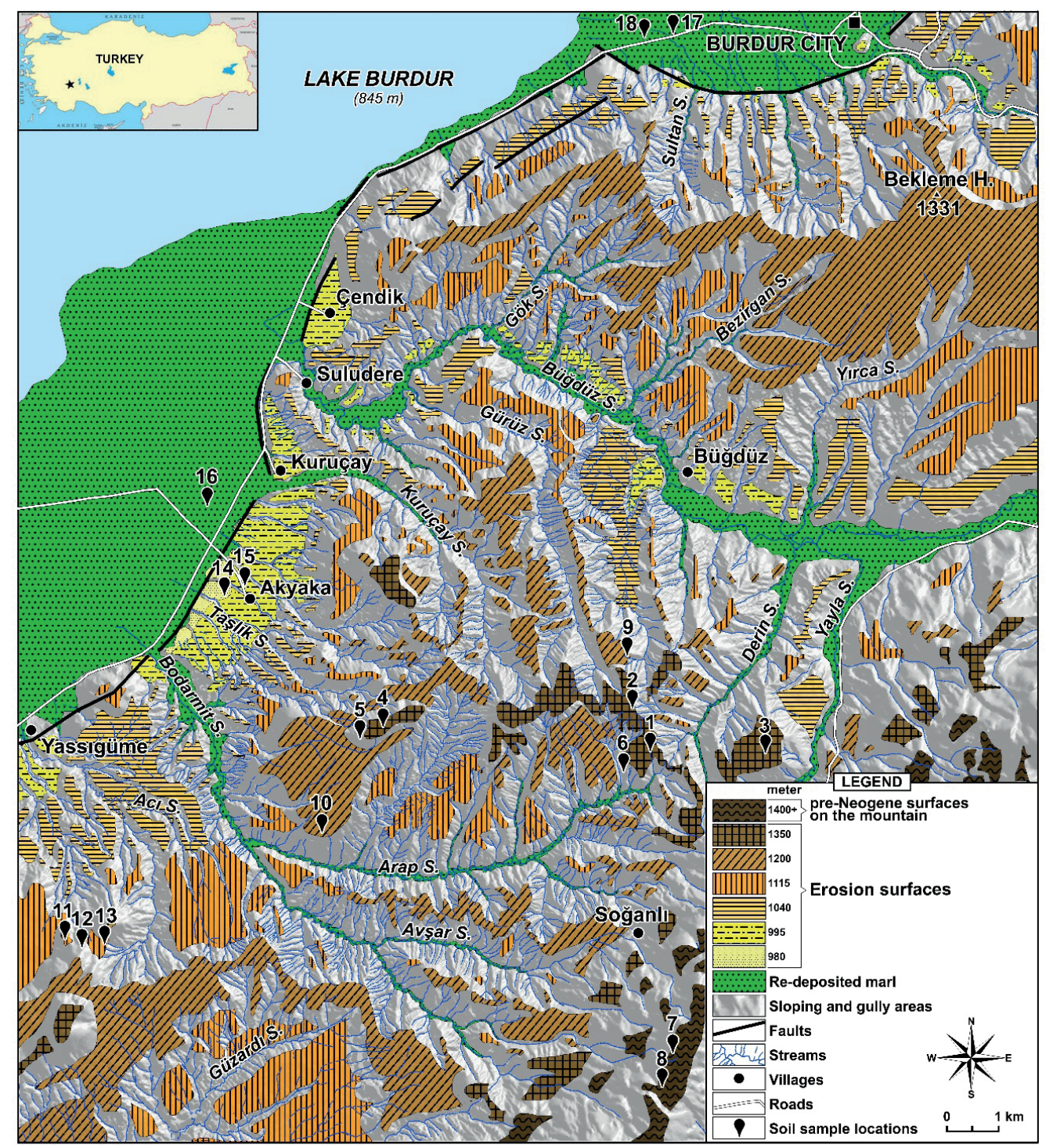

Figure 4: Geomorphic map of faulted topography in the eastern part of the Burdur Basin.

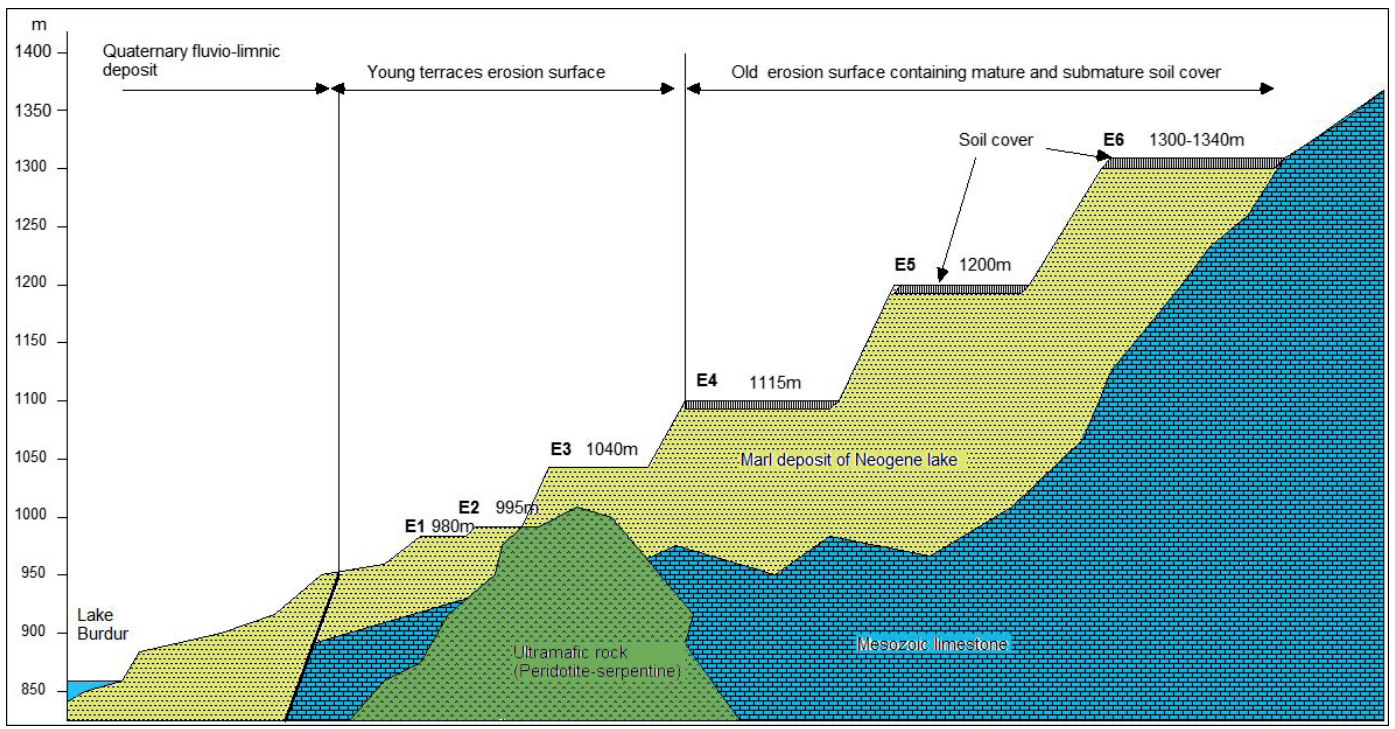

Figure 5: Erosion surfaces on marl deposit in the eastern part of the Burdur Basin. 


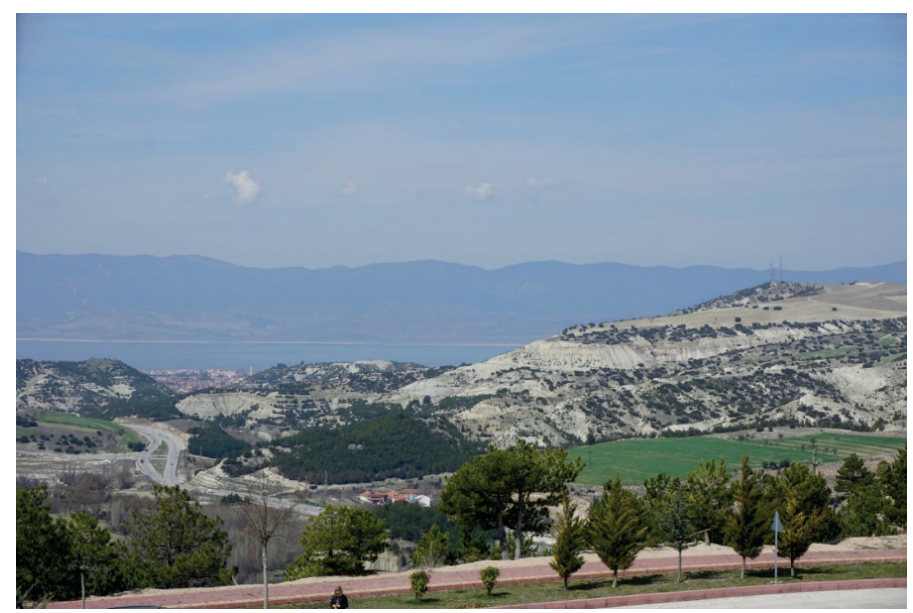

Photo 6: A general view from the Mehmet Akif University Campus to Lake Burdur and the erosion surfaces devoted to agricultural fields.

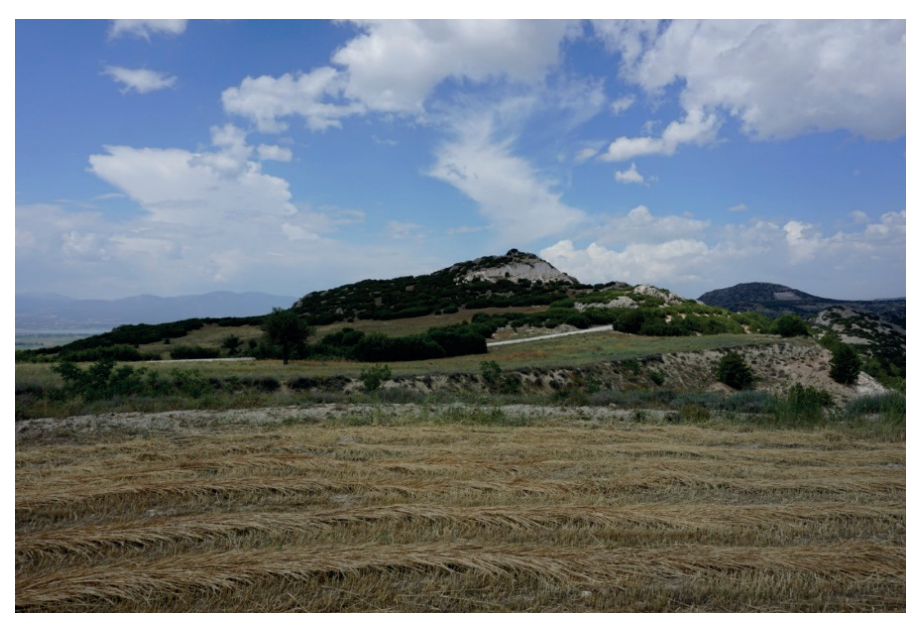

Photo 7: Erosion surface with a wheat production field at an elevation of 1,200 $\mathrm{m}$ on the marl deposit in the southeast of the Burdur Basin.

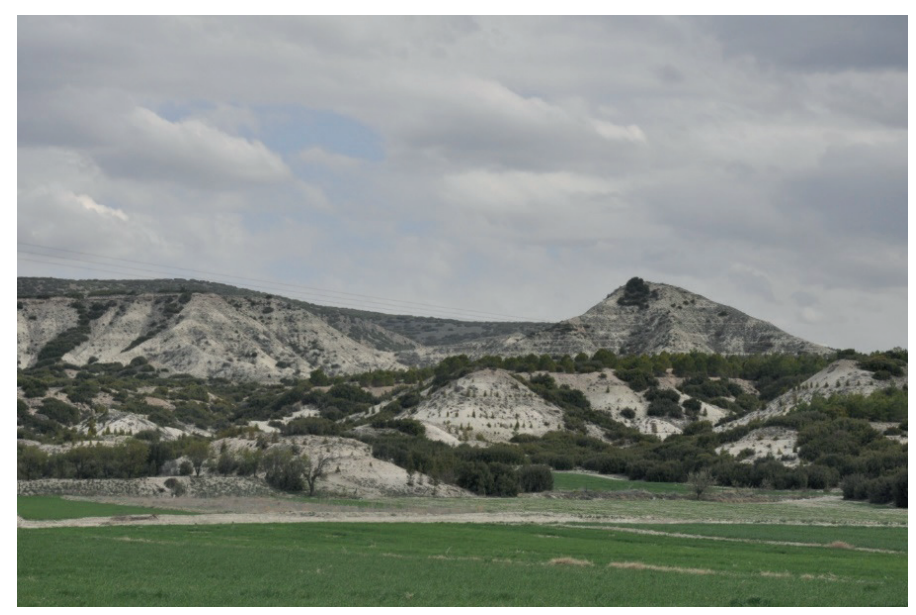

Photo 8: Three erosion surfaces developed on the marl deposit at an elevation of 980,995 and $115 \mathrm{~m}$ in the southeast part of the Burdur depression. grains requirements (Figure 4, Photo 6-8). Some parts of the erosion surfaces are mainly meadow areas mostly for goats. The kermes oak (Quercus coccifera) communities, which are very resistant against drought, are widespread on the gentle valley slopes. The spiny leaves and seeds of kermes oaks are eaten by goats during the year. On the other hand, misfit valleys with a wide valley on the upper erosion surface imply the remnant of an old drainage pattern. The lower erosion surfaces, which are found at an elevation of 980 and 995 m, cover a small narrow strip of land, and here, agricultural fertility is very low due to stony marl deposit and semi weathered marl deposit.

At the same time, the erosion surfaces are one of the best indicators of the lowering of the base level of Lake Burdur. Profiles that are drawn A-B-C and D-E in the direction of NW$\mathrm{SE}$ in the southeast of Burdur Lake show the presence of an erosion surface at an elevation of 980, 995, 1,040, 1,115, 1,200 and 1,300-50 m (Figure 1, 6).

As to soil formation on the erosion surface, there is a close relationship between the relative age of the erosion surface and soil formation. Indeed, rendzina soil or Rendzic lepotosol has developed on the upper erosion surfaces at an elevation of 1,115, 1,200 and $1,300 \mathrm{~m}$. Here, the thickness of rendzina increases from the $1,115 \mathrm{~m}$ erosion surface to the $1,300 \mathrm{~m}$. There is no soil cover on the erosion surface at an elevation of 980, 995 and 1,040 $\mathrm{m}$ due to insufficient time having elapsed (Figure 4).

Erosion surfaces are also seen on the conglomeratesandstone, peridotite-serpentine and limestone in the western part of the Lake Burdur Basin, but their altitudes do not correspond to the erosion surfaces that developed in the eastern part of Lake Burdur Basin. This is because the erosion resistance of conglomerate, limestone and peridotite-serpentine is higher than the marl and the same faulting movements did not occur in the western part of the Burdur Basin.

\section{Valley shapes}

Valleys crossing the fault scarp contain deep and triangular facets, knickpoints and terraces showing the rejuvenation process depending on the faulting movements. The formation of these valley shapes is briefly explained in the following paragraphs.

"V" shaped valleys. The fault scarp lying in the eastern part of the Burdur basin has been deeply dissected as triangular facets by the streams flowing into Lake Burdur. The deepening of valleys increases from the old erosion surface to lower ones. 


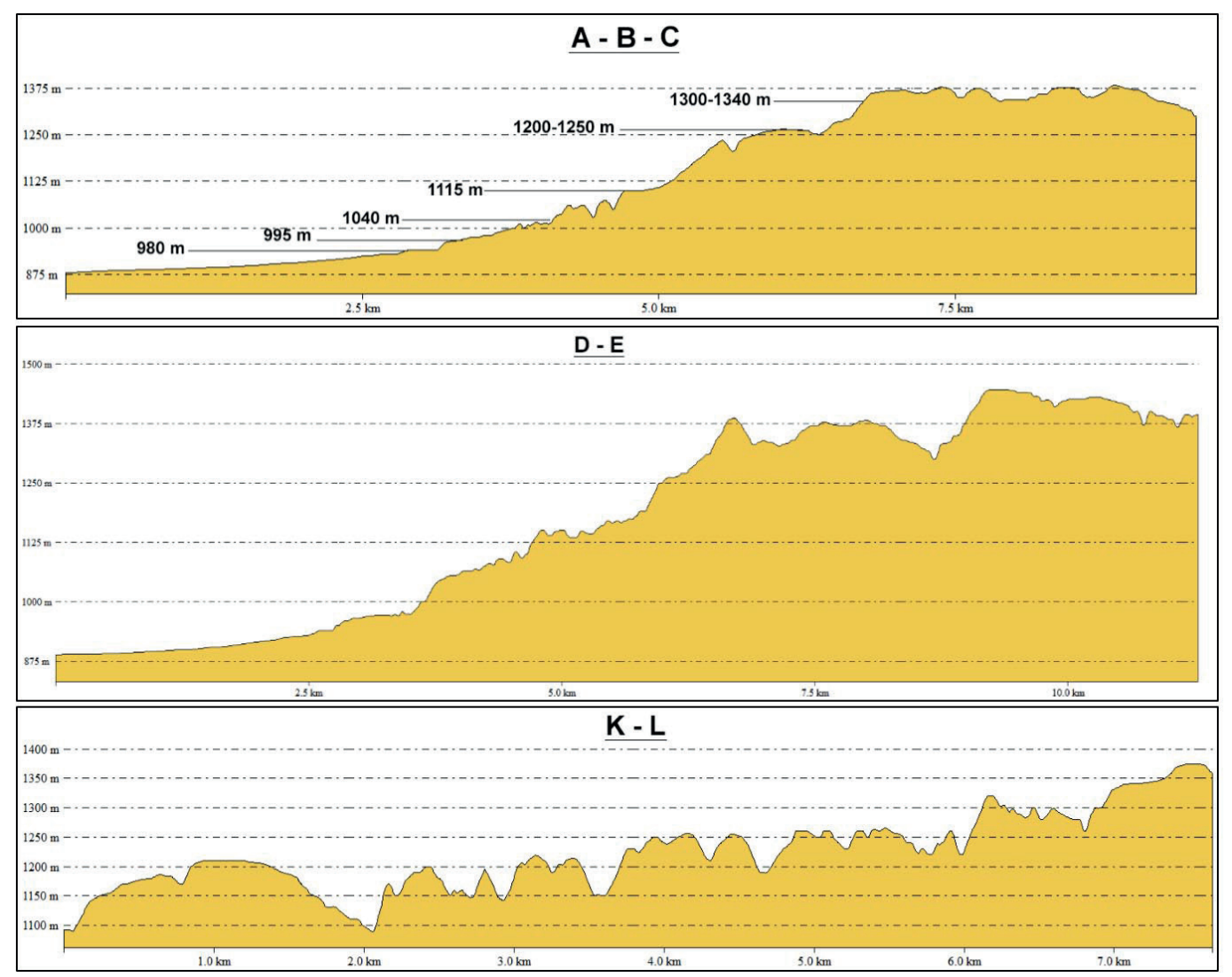

Figure 6: The profiles showing erosion surfaces and the dissecting of topography in the direction of roughly E-W in the SE of the Burdur Basin.

Wide misfit valleys on the upper erosion surface convert to "V" shaped valleys toward the fault scarp. This is related to the intensity of backward erosion occurring in the valleys. The drop of the base level of the Burdur Basin at each faulting period has resulted in intense backward erosion and the carving of the valley bottom. Thus, triangular faced valleys or "V" shaped valleys have been formed along the fault scarps. The increase of the inclination of the valley slope has caused the formation of gully erosion on marl deposit because marl deposit with low infiltration capacity has led to an increase of the surface flow or runoff. Thus, the transporting of the withered, disintegrated materials via runoff on the marl surface is the main reason of the gully erosion in the places where natural vegetation cover was destroyed and degenerated (Atalay et al., 2019b, c).

The slopes of valleys crossing the fault scarp have also been dissected into secondary gullies by the runoff. The inclination, which is seen on nearly $100 \%$ of the valley slopes, has been caused by debris flows on the weathered marl. This debris flow occurring on the valley slopes prevents the growth of vegetation because the seeds of the herbaceous vegetation and Calabrian pine (Pinus brutia) are continually transported with the debris flow.
Knickpoint, which is a break in the long profile of a river valley, has been formed in accordance with the backward erosion continuation that occurred at each faulting movement in the study area. The knickpoint longitudinal profiles of Bugdüz, Bordamit and Koru streams flowing into Lake Burdur are found at an elevation of 980, 1,020, 1,100 and 1,200 m (Figure 7). The elevation of the knickpoints clearly reflects the fluvial erosion rejuvenation which depends on the lowering on the base levels at each faulting movement in the Burdur Basin. Knickpoint altitude also corresponds to erosion surfaces.

Terrace levels in the transversal profile of the valley also show the rejuvenation phases of the fluvial erosion depending on the drop of the base level of Burdur Basin. The lowering base level of Lake Burdur at each faulting period caused to begin a new rejuvenation stage in the valley. In other words, streams cut into their valley, subsequently leaving only remnants on the old valley floor preserved above the new one. Such an elevated surface is called a river terrace. When examining of transversal profile of M-N crossing the upper level of the south-eastern part of the Burdur Basin the terraces resembling knickpoint and levelled surface were established at an elevation of c. 1,050,1,100,1,150, 1,200, 1,250 and 


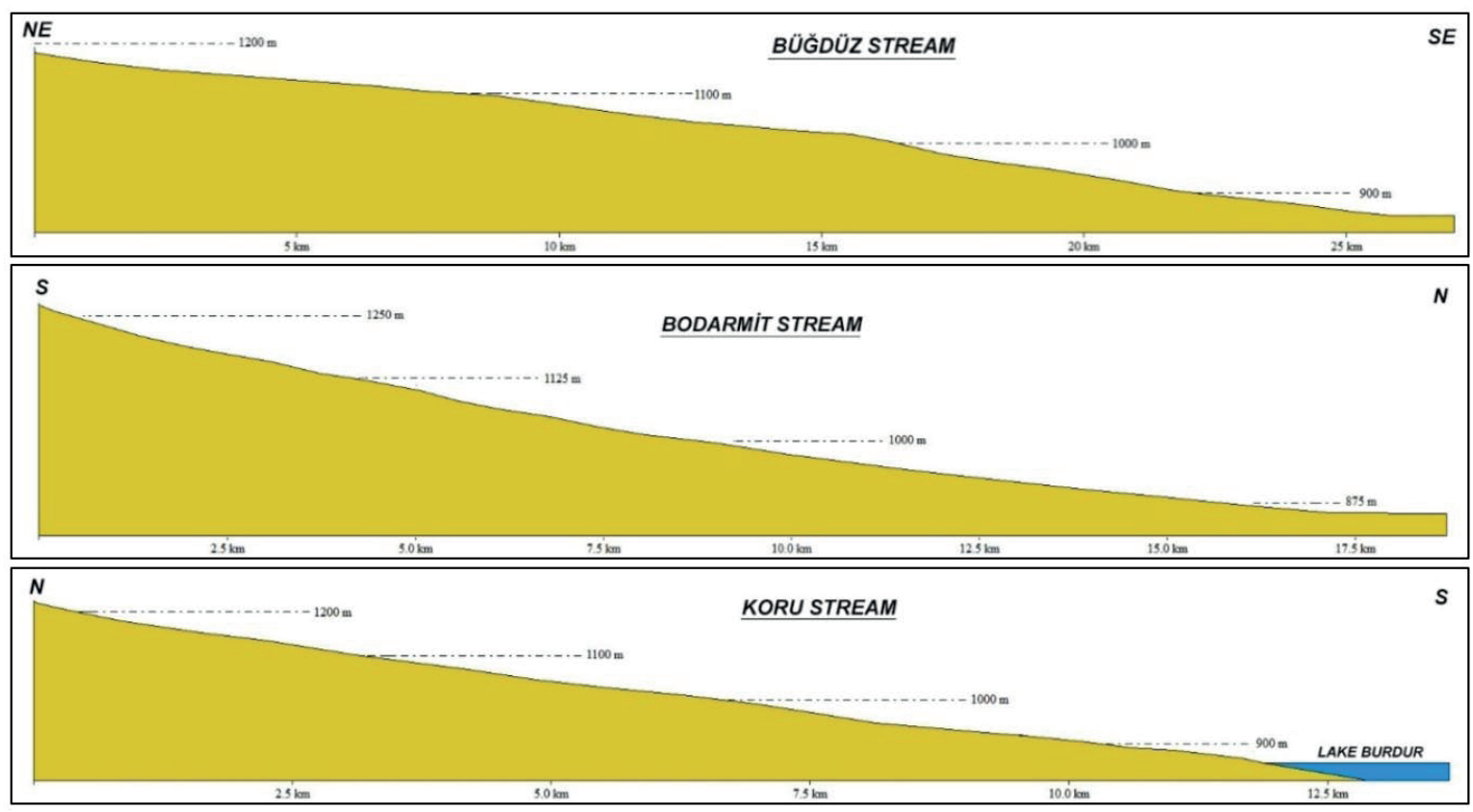

Figure 7: Knickpoints of the SE of Burdur basin and Koru stream valley in the SW of the Burdur Basin.

$1,300 \mathrm{~m}$ in the Bugdüz stream flowing into Lake Burdur (Figure 9). The terrace levels were at an elevation of 11,225, $1,250,1,375$ and $1,500 \mathrm{~m}$ in Koru stream valley in the N-S direction.

There is close correspondence among the erosion surface, knickpoints in the longitudinal profile of main stream and terrace levels in the transversal profile of the main valley reflecting the rejuvenation of the erosion depending on the drops of base levels in the Burdur Basin (Figure 5-7).

Dissecting amount of topography. The amount of evacuation and/or dissecting of topography between the upper level and lower level of erosion surface is more than $300 \mathrm{~m}$. In other words, the relative altitude between the valley bottom and watershed line of the valley exceeds $300 \mathrm{~m}$ (Figure 8, 9).
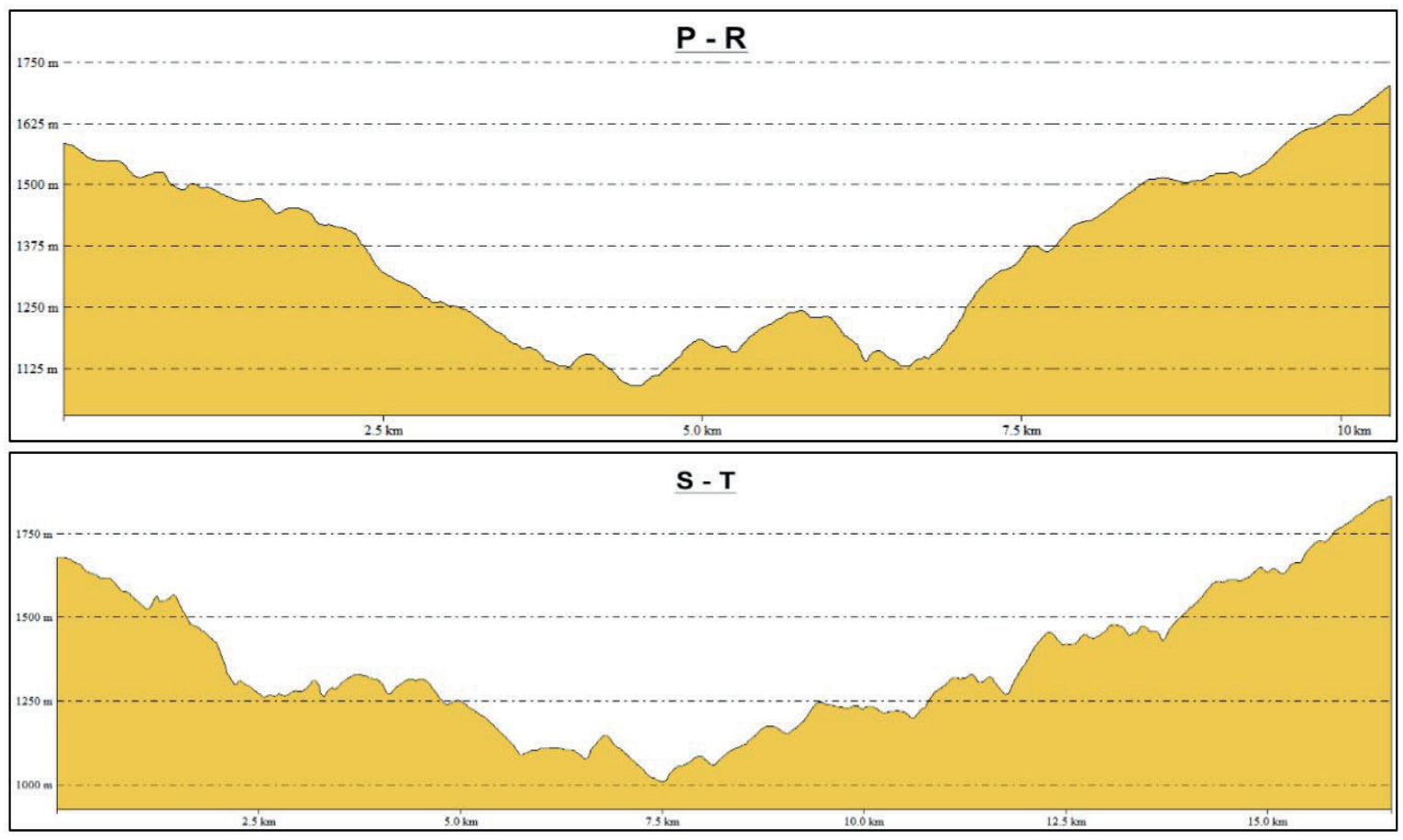

Figure 8: Terraces and the amount of evacuation or erosion on the transversal profile of the Koru valley in the SW part of the Lake Burdur Basin. 


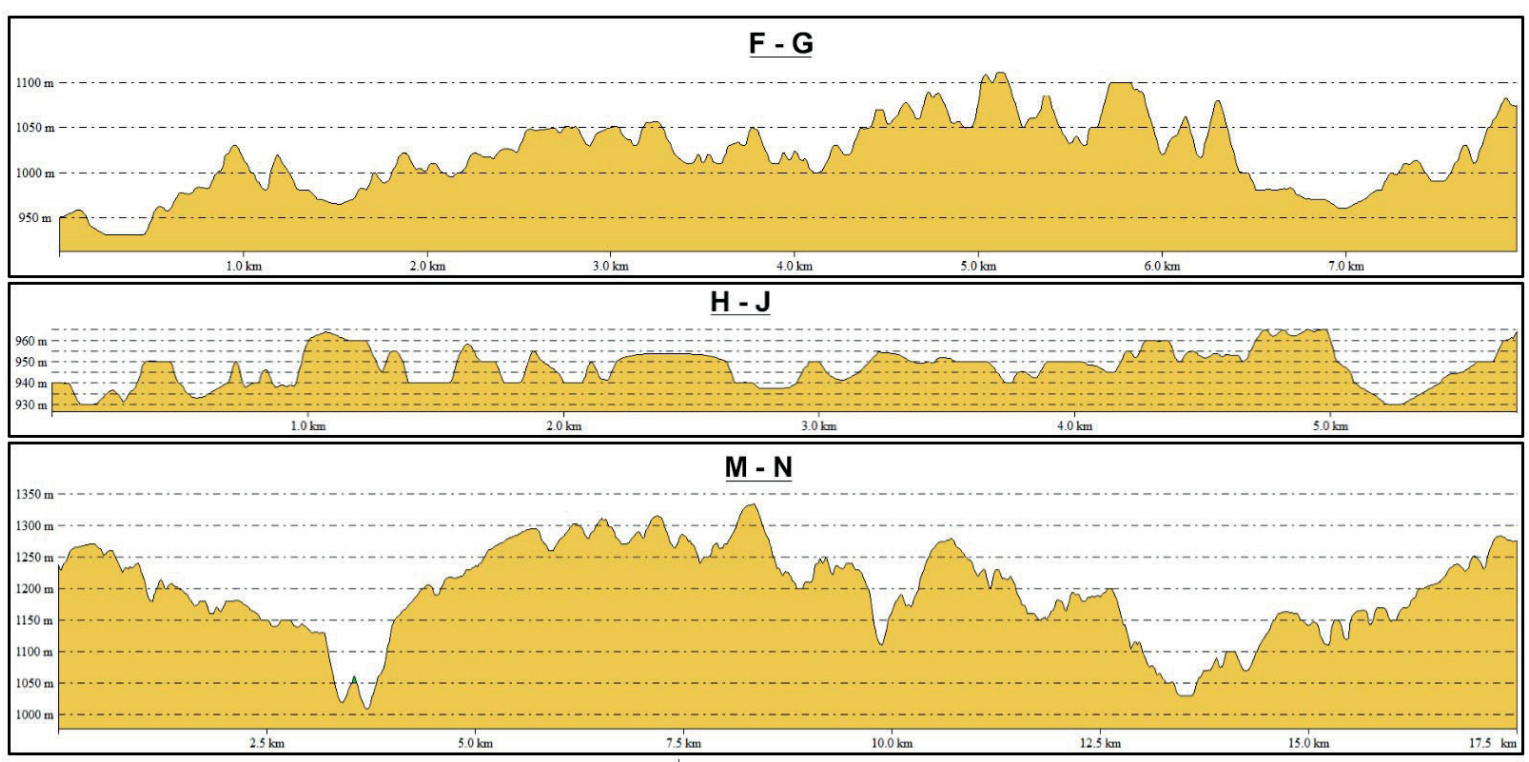

Figure 9: The amount of evacuation and/or dissecting of topography with deepening of valleys in the east of the Burdur BasinBasin.

The basement composed of peridotite-serpentine and limestone has been outcropped on the deeply incised valley bottoms. The exposure of basement rocks composed of melange, peridotite-serpentine and Mesozoic limestone is related to enormous removal of marl deposit. Exhumed surfaces are seen between the Hacilar and Bugdüz villages in the southeast of Burdur Depression.

It can be stated that erosion surfaces, knickpoints, and terraces clearly show the presence of polycyclic faulted topography in the Burdur Basin.

\subsection{Tectonic evolution and the formation of faulted} topography in the east of Burdur Basin

Tectonic evolution and the formation of the Burdur Basin are expressed following a geological period depending upon the field observations and transversal and longitudinal profiles of valleys (Figure 10).

\section{A. Middle Miocene Faulting Period}

The faulting movements, which occurred during the MiddleUpper Miocene, play an important role in the shaping of the present day topography of Turkey. In fact, many tectonic depressions have been formed along the Northern Anatolian and East Anatolian fault Zone. The vertical faulting movements are responsible for the formation of the horst-graben system on the Menderes Masse in the western part of Aegean Region. In this period, the present-day Burdur basin collapsed along the main fault line. Thus, the initial phase of Burdur Graben formation was formed.

\section{B. Upper Neogene sedimentation period}

The Burdur Graben area was occupied by a lake in which calcareous sediment-rich clay sediments derived from the Mesozoic limestone and partly weathered product of peridotiteserpentine were accumulated under the sedimentation conditions on the serpentine-limestone basement of the depression. According to the discordance in the middle section of the Neogene deposit, the second lake sedimentation occurred, but there is no difference in total stratification properties of the Neogene lake deposit. Toward the upper section of the Neogene deposit, seldom fluvial gravelly layers are seen indicating the regression and transgression fluctuation phases of the lake environment (Photo 2, 3).

The Miocene and Pliocene (Neogene) marl surfaces lie at an elevation of 1,300-1,350 m, and its thickness is estimated to be $350-400 \mathrm{~m}$.

\section{Pliocene faulting period}

Probably at the end of Miocene or Upper Pliocene the Burdur basin was depressed along the main fault line passing through the eastern part of the present-day depression. 


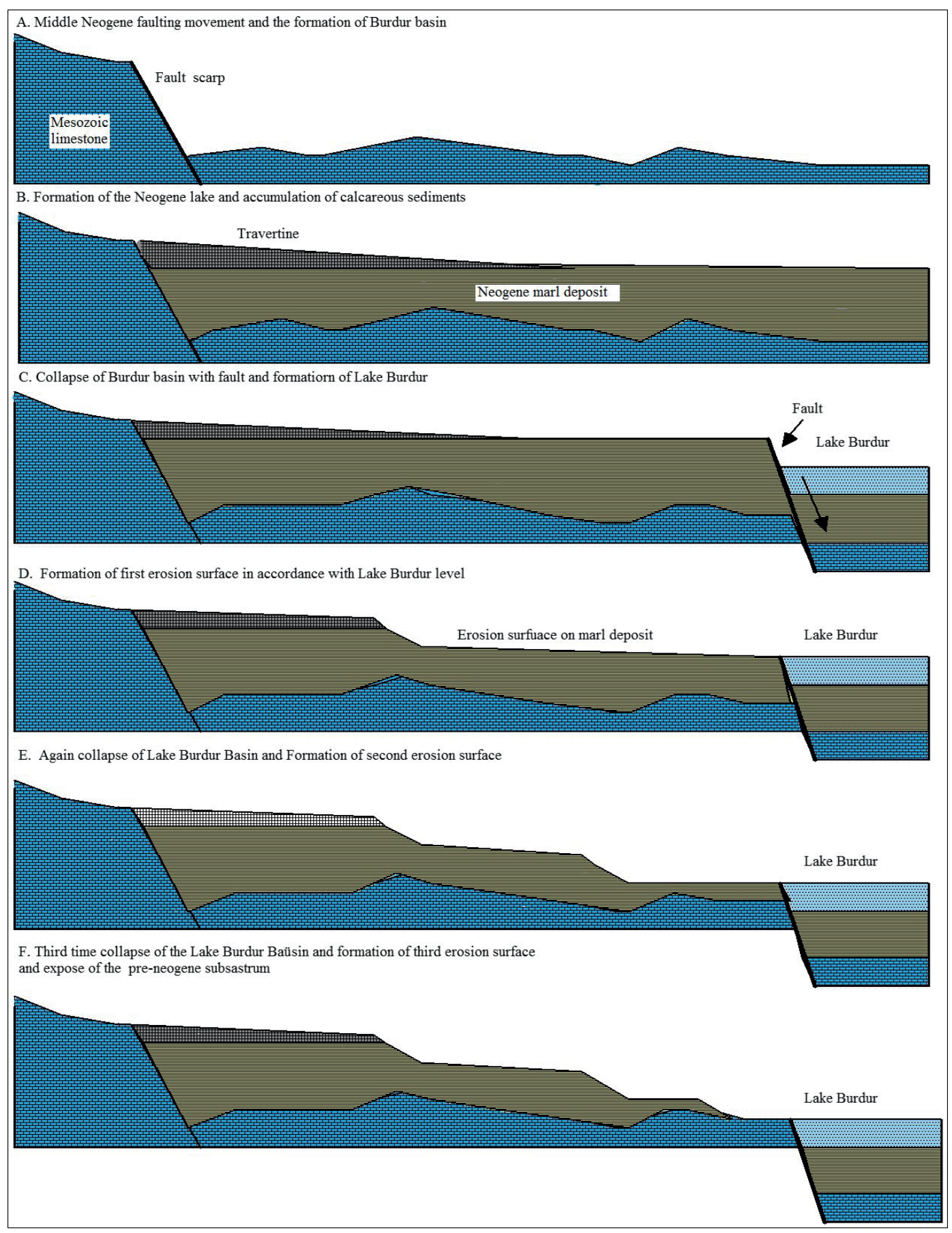

Figure 10: Geomorphological evolution stages according to geologic periods in the Lake Burdur Basin.

\section{D, E, F. Faulting movements and rejuvenation of fluvial erosion}

The Neogene marl deposit in the eastern part of the Burdur Basin has been cut at a high-angle along normal faults. According to erosion surfaces and knickpoints the main fault lines passing the eastern part of the Burdur basin has been rejuvenated six times. In other words, reoccurrences of faulting movements in the Burdur main fault are the main reason of rejuvenation processes and the formation of erosion surfaces. The base levels controlling the erosion and deposition processes are as follows:

The erosion surface at an elevation of $1,300-1,340 \mathrm{~m}$ is the original surface of the Neogene deposit. The erosion surfaces at an elevation of $1,200,1,115,1,040,995$ and $980 \mathrm{~m}$ were developed by each faulting movement. As mentioned before, the 
lowering of the base level of the Burdur Basin in each faulting movement is the main reason of the formation of erosion surfaces (Figure 4, 5, 10).

The fluctuation of the lake levels during the Last Glacial and Early Holocene

As it is known, during the glacial period some depressions, like the Konya-Ereğli basin occupied by a lake and present lake levels that are found in the closed basin, were subjected to the rise due to low evaporation during the Last Glacial period called Würm in Anatolia (Kazanc1 et. al. 2012). The level of Lake Burdur was raised to $1,000 \mathrm{~m}$ of the elevation during the maximum phase of the last glacial period c. 20K BP (before present). The delta deposit occurring at the location of Soğanl1 village in the southwest of Burdur Lake indicates clearly that the levels of Lake Burdur have risen. The other lake terraces of Lake

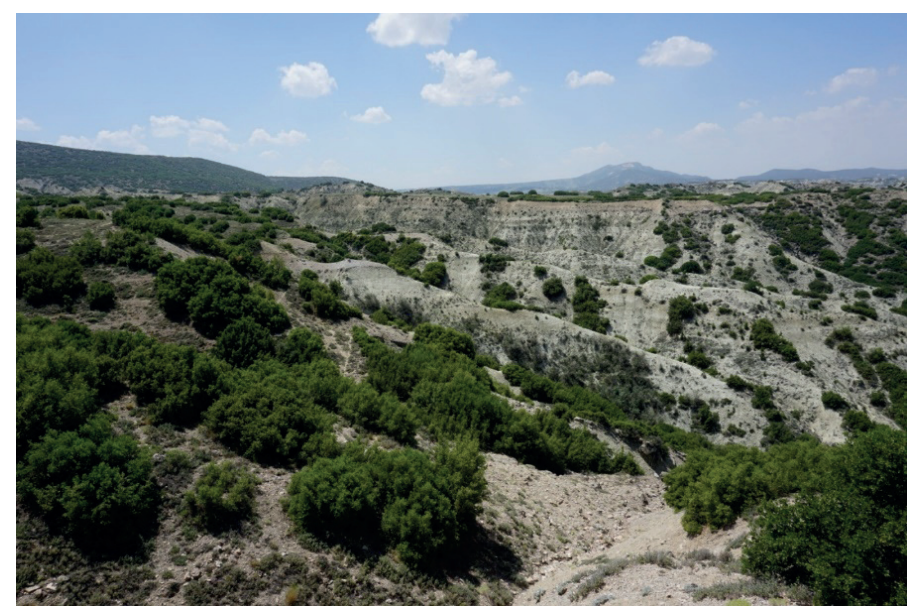

Photo 9: The upper erosion surface dissected with gullies at an elevation of 1,200 $\mathrm{m}$ in the east of the Burdur Depression.



Photo 10: Deltaic deposit formed in the Lower Holocene cut by the young fault in the east of Burdur city.
Burdur were found at an elevation of 955 and $910 \mathrm{~m}$ (Cohen and Erol, 1969; Erol, 1973; Sungur, 1974; Atalay, 1977).

There is some problem in discussing the terraces and/or erosion surface at the lower levels, whether belonging to lake terraces and fault scarps. The lower level erosion surfaces at 980 and $995 \mathrm{~m}$ occurring between Hacilar and Akyaka villages in the SE part of Lake Burdur belong to the youngest lake levels that formed from collapsed levels of Lake Burdur because the delta deposit that cut the fault may indicate the youngest faulting movement which occurred during the Holocene in the vicinity of Burdur city. It can be stated that the lower erosion surfaces do not show the Holocene lake level of Burdur (Photo 10).

The effects of the Faulted topography on the natural environment assessment

The fault scarps and valleys on the fault scarps are one of the very vulnerable or sensitive areas of land degradation. Soil and parent material erosion continues to be severe especially where natural vegetation has been destroyed. The low water infiltration capacity of marl deposit on the fault scarp and valley slopes leads to the formation of torrential floods. A torrential flood causes sedimentation on the agricultural fields and settlements in the Burdur Plain. The faulted topography of the study area is one of the desertification and land degradation areas of Turkey (Atalay et al., 2019a, b). The destruction of the natural vegetation, especially Calabria pine (Pinus brutia) and kermes oak (Quercus coccifera), has led to floods and intense erosion, and the marl material transported from the gully areas of the fault scarp has contributed to the formation of colluvial deposit and dejection fans on the edge of the main Burdur fault line. Re-deposited marl deposit on the SE of the Burdur depression is the main dry farming area of the study area.

The destruction of Calabrian pine forest and maquis vegetation, notably kermes oak (Quercus coccifera), over grazing and misuse of land has resulted in intense floods affecting agricultural and settlement areas in the vicinity of Burdur city. In order to prevent erosion and flood control, the Soil Conservation Group Directory was established in 1967 in Burdur City. The erosion and flood events have been considerably prevented with the reforestation and afforestation application and dike constructions on gully areas and torrential stream valleys.

On the other hand, the accumulation of fine sediment derived from the marl deposit in the lowland creates an environment for agricultural production. Meanwhile, re-deposited marl deposit 
on the Burdur Basin is the main occurrence areas of dry farming. The faults and faulted topography areas of the Burdur Basin is one of the main earthquake zones of Turkey. Earthquakes have occurred since pre-historical time.

\section{RESULTS AND DISCUSSION}

The results obtained from this study are outlined below:

1. Vertical tectonic movements were the main factors responsible for the formation of grabens and the intermontane basin in the Lakes Regions, which are the transitional geomorphologic unit between eastern continuation of the Taurus orogenic belt and the Menderes Palaeozoic metamorphic masse.

2. The collapsed areas were occupied by lakes in which marl deposit was accumulated.

3. The erosion surfaces, knickpoints and terraces clearly indicate reoccurrence of faulting movements.

4. Erosion surfaces correspond to agricultural fields on which mainly cereals are harvested, and the Neogene deposit on the depression is also the main agricultural field in the study area.

5. The soil formation process and the thickness of the solum horizon clearly show the relative age of the erosion surfaces. Indeed, soil belonging to rendzina and/or Rendzic Leptosol, have developed on the old erosion surface at an elevation of 1,200 and 1,300-1,350 m. (Atalay et. al, 2019a). Faulted topography forms are an example for soil catena especially both toposequences and crinosequences showing soil formation depending on altitudinal topographic properties and the relative ages of erosion surfaces (Atalay, 2016).

6. Faulted topography in the study area is different from other faulted topography in Anatolia because faulting movement phases occur much more frequently than other resembling areas.

7. Fault scarp dissected by triangular facets are very vulnerable areas for land degradation.

Peer-review: Externally peer-reviewed.

Conflict of Interest: The authors have no conflict of interest to declare.

Grant Support: The authors declared that this study has received no financial support.

Hakem Değerlendirmesi: Dış bağımsız.

Cıkar Çatışması: Yazarlar çıkar çatışması bildirmemiștir.

Finansal Destek: Yazarlar bu çalışma için finansal destek almadığını beyan etmiştir.

\section{REFERENCES/KAYNAKÇA}

Altunbaş, S. (2018). Pedogeomorphology of the Burdur-Gölhisar Basin, SW Anatolia, Turkey. Fresenius Environmental Bul. 28(1-2),139-149.

Ardel, A. (1951). Göller Bölgesinde morfolojik müşühadeler. Coğrafya Enst. Derg., 2, 1-15.

Atalay, İ. (1977). Burdur havzası ve çevresinin jeomorfolojik gelişimi (Geomorphological evolution of the Burdur basin and its surroundings). Jeomorfoloji Dergisi, 6, 93-110.

Atalay, İ. (2007). Effects of neotectonic movements in shaping of the North-western part of Taurus Mountains, Turkey. (Ed.) Atalay, Efe, Ielenicz and Balteanu. Ecology and Environment from Carpathians to Taurus Mountains. Proc. of the 5th Turkey-Romania Geographical Academic Seminar içinde pp. 63-78.

Atalay, İ. (2013). Tektonik hareketlerin Türkiye Doğal Ortamı üzerindeki etkileri. Effects of the tectonic movements on the Natural Environment of Turkey. Prof. Dr. İlhan Kayan'a Armağan, Ege Üniv. Yay., s. 341-354.

Atalay, İ., (2016). Toprak Oluşumu Sinfflandirllması ve Toprak Coğrafyası (5. Baskl), Meta Basım, İzmir.

Atalay, İ., Tonbul, S., Cürebal, İ., Soykan, A. (2017). An Approach for the Dividing into Geomorphological Region of Turkey. (Ed.) S. Tonbul. T. Şengün, M. Siler, A. Canpolat. International Symposium on Geomorphology, 12-14 October 2017, Proceeding Book içinde, 20-30.

Atalay, İ., Adıgüzel, H., Dal, N. (2017a). Geomorphological evolution of the Gölhisar Depression, SW Anatolia, Turkey. (Ed.) S. Tonbul. T. Şengün, M. Siler, A. Canpolat. International Symposium on Geomorphology, 12-14 October 2017, Proceeding Book içinde, 137-145.

Atalay, İ., Adıgüzel, H., Dal, N. (2017b). The effects of neotectonic movements on the geomorphic units between Lake Ac1 and Lake Akgöl, SW Anatolia, Turkey. (Ed.) S. Tonbul. T. Şengün, M. Siler, A. Canpolat. International Symposium on Geomorphology, 12-14 October 2017, Proceeding Book içinde, 644-648.

Atalay, İ., Altunbaş, S. (2019). Main Reasons and Results of the Land Degradation in Turkey. (Ed.) A. Nallı, O. C. Turgay. M. V. Akça, Proc. of $10^{\text {th }}$ International Soil Congres. Succesfull transformation toward land degradation neutrality 17-19 June 2019 içinde, 75-81.

Atalay, İ. Altunbaş, S. and Siler, M. (2019a). Burdur-Gölhisar havzasinin ekolojisi, ekosistemleri ve mermer ocaklarinin rehabilitasyonu- The Ecology, ecosystem and rehabilitation of marble quarries of Burdur-Gölhisar Basin, SW Anatolia. Orman Genel Müdürlüğü Yay. Ankara.

Atalay, İ., Altunbaş, S. and Siler, M. (2019b). The Importance of Marl Deposits on the Soil Formation, Land-Use and Land Degradation in Turkey. (Ed.) A. Nall, O. C. Turgay. M. V. Akça, Proc. of $10^{\text {th }}$ International Soil Congress. Successful transformation toward land degradation neutrality 17-19 June 2019 içinde, 82-89.

Cohen, R. and Erol, O. (1969). Aspects of the Paleogeography of southCentral Anatolia. Geog Journal, 135, 338-398. 
Erinç, S., Bener, M., Sungur. K., Göçmen, K. (1971). 12 Mayıs 1971 Burdur Depremi. İ. T. Coğrafya Enst Yay. 66, İstanbul.

Erol, O. (1975). Burdur havzas1 Kuvaterner depolar1- Quaternary deposits of Lake Burdur: Cumh. 50. Yılı Yerbilimleri Kong., MTA, Enst. Yayınlart. s. 386-390.

Erol, O. (1981). Neotectonic and geomorphological evolution of Turkey: Zeitsehrift für Geomorphologie, Bd. 40, 193-211.

Erol, O. (1984). Geomorphology and neotectonics of the pluvial lake basins in the Taurus belt and South-Central Anatolia: Inter. Sym. on the geology of Taurus Belt, s. 119-124, Min. Res. and Exp. Inst. Pub., Ankara.

Kazanc1, N. and Gürbüz, A. (2012). Kuvaterner Bilimi. Ankara Üniv. Yay. No 350.

Lahn (İlhan), E. (1948). Türkiye göllerinin jeolojik ve jeomorfolojik etüdü hakkında. MTA Enst. Yay. Seri B 12, Ankara.

Louis, H. (1938). Eiszeitliche Seen in Anatolia. Zeitsch. Ges. F. Erdkunde, Berlin: pp. 276-283.
Strahler, A. H. and Strahler, A.N. (1992). Modern physical geography John Wiley and Sons Inc. New York, Brisbane, Toronto, Singapore Sungur, K. (1974). Burdur, Acıgöl depresyonlarl ve Tefenni ovasinın fiziki coğrafyası. İ.Ü. Coğ. Enst. Yay.: 95, İstanbul.

Ketin, İ, (1983). Türkiye jeolojisine genel bir bakış. İst. Tek. Üniv. Kütüp. No: 1259. İstanbul.

Şengör, C.A.M., (1980). Türkiye neotektoniğinin esaslart. Türk. Jeoloji Kur. Yay., Ankara.

Şengör, A.M.C. and Y1lmaz, Y. (1983), Türkiye'de Tetis'in evrimi: Levha tektoniği açısından bir yaklaşım. Türkiye Jeol. Kur. Yerbilimleri Özel Diz. No: 1.

Şaroğlu, F. and Yılmaz, Y. (1987). Doğu Anadolu'nun neotektonik dönemdeki jeolojik evrimi ve havza modelleri. MTA Derg. 107:73-94.

Thornbury, W. D. (2004). Principles of geomorphology: CBS publisher and Distribution PVT, LED.

Tchihatcheff, P. de. (1866-69). Asie Mineure description physique de cette contree. I. Geographie physique compare: IV Geologie, 3bdParis. 